\title{
HOW SHOULD THE CLASSROOM BE MANAGED DURING THE COVID-19 PANDEMIC?
}

\author{
E. Handayani Tyas ${ }^{1}$ and Lamhot Naibaho ${ }^{2}$ \\ ${ }^{1}$ Education Management Department, Postgraduate Program, Universitas Kristen Indonesia, Indonesia \\ ${ }^{2}$ English Language Education, Faculty of Letter and Language Education, Universitas Kristen Indonesia, Indonesia
}
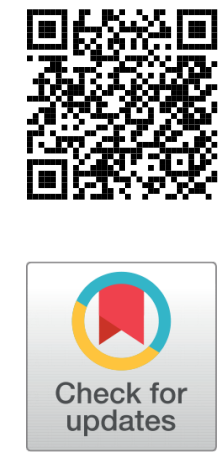

Received 6 May 2021

Accepted 20 May 2021

Published 31 May 2021

Corresponding Author

Lamhot Naibaho, lamhot.naibaho

@uki.ac.id

DOI 10.29121/

granthaalayah.v9.i5.2021.3943

Funding: This research received no specific grant from any funding agency in the public, commercial, or not-for-profit sectors.

Copyright: (C) 2021 The Author(s). This is an open access article distributed under the terms of the Creative Commons Attribution License, which permits unrestricted use, distribution, and reproduction in any medium, provided the original author and source are credited.

\section{ABSTRACT}

This study is about classroom management during the Covid-19 Pandemic. This study aims to find out how the classroom should be managed during the Covid19 Pandemic. It was done at Universitas Kristen Indonesia within three months, from February - April 2021. The method of the study is library research, where the researchers were the instruments of this study. To answer the problem of the study, the researchers collect some documents related to school management taken from online and printed journals, books, articles. The documents analyzed to provide the answers to this study were taken from the library and Google Scholar. The result of this study is that good and correct management requires commitment from all elements involved in school management, parents of students and community members who are members of the school committee, and the community in the school environment during the Covid-19 Pandemic. To run the school management smoothly, the leadership must apply the principles of transparency and professionalism. So it is concluded that those involved in the school management should cooperate, and transparency and professionalism should be implemented during the Covid-19 Pandemic.

Keywords: Pandemic19, School, Management

\section{INTRODUCTION}

School management is the key to success in achieving quality in managing schools because with good management, and schools will succeed in meeting the demands for quality education following national education standards. Good management (vision, mission, clear/focused goals, discipline, hard work, innovative work, competence, commitment, credibility, accountability, integrity, noble character, honesty, transparency, transformation, coordination, collaboration, communication etc.) will produce quality graduates Komoldit et al. (2018), Nadeak and Naibaho (2020a). A school principal should know about education/school management because with- 
out being equipped with managerial skills, a school principal will work only guesswork/guesswork/ roughly according to his opinion, so that 'like a loco, he will be released from his car'. Principals who do not study management theory will not achieve school goals effectively because achieving goals must be based on systematic behaviour related to the concepts, assumptions, and generalizations of management theory Bush (2006).

The more intelligent consumers are in assessing the quality (quality) of a product, automatically requiring business people and any business, including schools, to improve their products and services further. Therefore, professionals are well aware of the importance of quality management to continue to exist and advance amid today's intense global competition Schwab and Sala-I-Martín (2013). Over the past few years, many ventures, including completely unpredictable technological, economic, social schools, that managers who used to believe in the myth of stability are now thrown out of their belief. The large and middle school institutions, especially the small ones, began to grow one by one. Schools and their leaders are struggling to make various changes that are taking place very quickly and evaluate the impact of these changes if they are to survive.

School management must find innovative solutions in solving various problems that interfere with the school organization, especially daily challenges. Various changes require qualified managers who can work better by using the latest techniques and creative ideas that breakthrough- thoroughly - thoroughly - thoroughly (to think through, through and comprehensively) - especially working during the Covid-19 pandemic like now, which has been a year and who knows when it will end Tyas and Naibaho (2021b), Naibaho (2021a). Currently, management demands comprehensive skills and expertise, and the managerial scope must be comprehensive and transformative. Managers can keep up with new skills, especially in IT (Information and Technology), to answer needs in a turbulent and unpredictable environment. The world of education experiences the Covid-19 pandemic in Indonesia, but the whole world is feeling the consequences Nadeak et al. (2021), Nadeak et al. (2020).

By studying school management, it is hoped that it will understand the crucial problems faced by the world of education. Especially schools, because through school/community-based quality improvement management learning, it is hoped that it can provide in-depth knowledge and understanding of basic concepts, functions and roles, processes and procedures, positions and roles as reliable educators and education personnel. One of the educational problems faced by the Indonesian nation is the low quality of education at every level and education unit, so it is considered urgent enough to make various efforts to improve the quality of education in every school Naibaho (2014a). Awareness of the importance of education which can provide hope and better possibilities in the future has encouraged various efforts and attention from all levels of society to the steps and developments of the world of education. 
Various indicators, such as the development of national and local curricula, increasing teacher competence through training, procurement of books and learning resources/media, procurement of educational infrastructure and facilities, have not supported the improvement of the quality of school management as expected. Based on this fact, various questions arise, such as, among others, what is wrong in our educational administration? Admittedly, some schools, especially those in cities, have shown quite encouraging improvements in the quality of education, but on the other hand, others are still apprehensive. Learning that is conducted online has many problems with the network. Not all of the educational resources are digitally literate. Not all of the conditions in the territory of the Republic of Indonesia can be reached by the internet Nugroho (2010). To get a good signal, educators and students must look for a strong signal (up to the hill) because what often happens when learning from home experiences a broken signal, power outages, computers/laptops and cellphones that have to take turns, etc.

Optimizing resources concerning school empowerment is the most appropriate alternative to create an independent school with high excellence. Empowerment is intended to provide broader autonomy in solving problems in schools. It requires a policy change in education management with the principle of providing authority in managing and making decisions according to the demands and needs of each school locally Tyas and Naibaho (2021a), Naibaho (2021b). Regional autonomy has been implemented since 2001. Along with that, almost all development fields are autonomous, including education. Autonomy in education is carried out in stages, namely at the provincial, district/city and school levels. Autonomy at the school level is known as school-based education management or School-Based Management (SBM) Katuuk (2014). Through various studies, it was found that one of the weaknesses of schools was how to implement SBM with a focus on School-Based Quality Improvement Management (SBQIM) Hadijaya (2015).

School as an educational institution is a place (container) for the educational process to be carried out and has a complex and dynamic system. In its activities, a school is a place that is a place for educators and students to gather and in one interrelated order. Therefore, the school is seen as an organization that requires management. The role of management requires managers who are competent, full of dedication, have strong work motivation, are resilient and diligent, so they do not give up easily when faced with failure. Precisely with a high commitment of a manager, working hard and working innovative (work hard and work-wise), managers will dare to make breakthroughs to make innovations if they face obstacles that prevent the vision, mission and goals of the school Traitler (2015), Venter (2006). The seriousness of education officials, school supervisors, school principals, educators, parents, and students to work together to do the best work and always be based on an honest and wise attitude.

The implementation of SBQIM in schools is required to implement school programs and ensure the quality of all aspects of the implementation and educational 
outcomes. In addition, schools must also capture moments of autonomy and carry out self-reform to improve their performance. The self-reform that schools need to do is to improve the educational process starting with changes in the attitudes, culture and society of school administrators as well as the utilization of existing resources, carried out in the best possible way so that the implementation of SBQIM is successful, effective, efficient and optimal. Furthermore, the core activity of school organizations is managing Human Resources, which are expected to produce quality graduates following the demands of society's needs, and in turn, school graduates are expected Naibaho (2014b).

Education is not a simple endeavour but an activity that is dynamic and full of challenges, especially in "difficult" times because of the corona. Education will always change along with changing times, and every time education is always the focus of attention and often becomes the target of dissatisfaction because education concerns the interests of all people, not only regarding investment and living conditions in the future but also regarding the conditions and atmosphere of life now. That is why education always requires improvement and improvement in line with the increasing needs and demands of community life Kolibu et al. (2021). To improve the quality of education, of course, it cannot be separated from the quality of human resources and the increase in the social status of the nation's people. Therefore, schools need to be managed, regulated, organized, and empowered to produce optimal products or results. Internally, the school has a set of educators, students, curriculum, infrastructure, and facilities; externally, the school owns and relates to other agencies vertically and horizontally. In education, schools have stakeholders (who have an interest), including educators, students, society, government, the business world. Hence, schools need accurate management (management) to provide results that follow all parties' needs and demands Reeves (2009).

Schools that are the community's choice, namely schools with quality graduates, are 'assessed' well by the community. To realize such schools, a change in policy in education management is needed to provide authority in management and decisionmaking according to the demands and needs of each school locally Kristiana (2019). It can be ascertained that policy change in its implementation is not a simple matter. Policy changes require the readiness of various resources and the ability of managers at the school level. However, more important is an adequate understanding and readiness to know what and how schools should carry out the new system in decentralization. Some of the main reasons that demand policy changes in school management include the demands of the community's educational outcomes due to changes in socio-political, economic and cultural policies.

\section{RESEARCH METHOD}

The method of the study is library research, where the researchers were the instruments of this study. This study aims to find out how the classroom should be man- 
aged during the Covid-19 Pandemic. It was done at Universitas Kristen Indonesia within three months, from February - April 2021. To answer the problem of the study, the researchers collect some documents related to school management taken from online and printed journals, books, articles. These documents analyzed to provide the answers to this study were taken from the library and Google Scholar.

\section{DISCUSSION}

Some of the juridical foundations in the implementation of the education system in Indonesia are as follows: a) the 1945 Constitution and its amendments; b) Law no. 20 of 2003 concerning the National Education System, Article 51 paragraph (1) "The management of early childhood, basic and secondary education units is implemented based on minimum service standards with the principles of school/madrasah-based management"; c) Law no. 25 of 2000 concerning the 2000-2004 National Development Program in Chapter VII concerning the Education Sector Development Program Section, precisely the target, namely, "the realization of school and community based management of education"; d) Law no. 32 of 2004 concerning Regional Government; e) Government Regulation No. 25 of 2000 concerning the Authority of the Government and Provincial Regions as Autonomous Regions; f) Government Regulation No. 19 of 2005 on National Education Standards, particularly school management standards, namely School Based Management; g) Decree of the Minister of National Education No. 044 of 2002 concerning the Establishment of the Education Board and School Committee; and h) Decree of the Minister of National Education No. 087 of 2004 concerning School Accreditation Standards, especially regarding School Based Management Kristiana (2019).

The various efforts made by the government and school administrators have not fully met the expectations of the community. It is based on the fact that there are still obstacles in the field caused by the complexity of educational problems in line with increasingly complex community needs. The higher the community's social life and the development of science and technology, the higher the community's social life demands Esteves and Vanclay (2009). These demands lead to education because people believe that education can answer and anticipate these various challenges.

Education is one of the efforts that schools can make as an institution where people hope for a better life in the future. Public support for the provision of primary education shows quite encouraging enthusiasm, as seen by many private educational institutions, both public and affiliated with certain religions. Community participation is also often manifested by the participation of parents in other activities in the school, which are accommodated in the School Committee and line with the implementation of School-Based Education Management Cheng and Chan (2000). The community's need for quality education is often faced by the internal conditions of educational institutions, such as the limited availability of qualified / professional educators/teachers, limited education costs, inadequate teaching and learning facil- 
ities, and a school environment that is not conducive. In addition, the change in the standard of learning success, which is getting higher to serve market needs, turns out to be more challenging to catch up, due to the less supportive learning environment, plus the "frightening" corona "attack" makes learning unable to be carried out offline.

With togetherness and participation between the community and the government, it is hoped that there will be significant changes in the field of education because indeed education requires changes towards continuous improvement through the management or management of education, and schools are responsible for carrying out activities to manage their programs effectively and efficient (mangkus and sangkil, Improving School Efficiency). It is hoped that the understanding of SBM can provide additional knowledge, insight to education managers to understand the culture and increase the quality and control of schools, and the participation of local stakeholders can improve/enhance school performance. As a quality educational institution, it certainly requires much money because it must provide a variety of good learning infrastructure and facilities to support the performance of educators, education staff and students Tyas et al. (2020), Malhoit (2005). Therefore, there needs to be a breakthrough for school principals to deal with changing situations and needs.

As a comparison, the MBS model has been tried in America, derived from Edward E. Lawler and his friends. It has had an impact on improving the quality of teaching and learning. It is due to a more effective mechanism, namely that decision-making can be carried out quickly and provide a new motivation to work as motivation for achievement to the principal in carrying out his duties as a school manager. In many cases, it was stated that SBM had had a positive impact as experienced by schools in several other countries such as New Zealand and Chile. For schools in Indonesia, the current idea and understanding of SBM is an exact moment, and whether we want it or not or like it or not, we are already in an era of globalization which is perceived as a 'world without borders, competition in the world of industry and trade. Impact also on the world of education. School management that is run half-heartedly and carelessly has no longer got a place in the community's hearts Nadeak and Naibaho (2019). Schools must compete even though they must remain side by side (to compete and to corporate), therefore embrace society and take advantage of its potential positively.

School as a system is composed of components of context, input, process, output, and outcome. Context affects the input, input affects processes, processes affect output, and output affects outcomes. Therefore, the principal should manage the school by planning, implementing, monitoring and evaluating (applying the principles of PDCA: Plan - Do - Check - Action). Context is an externality that affects education delivery and, therefore, must be internalized into school administration. A school that can internalize the context into itself will make the school part of the context and not isolated. If so, the school will become a community school and not a school in the community. Context includes advances in science and technology, com- 
munity values and expectations, government and community support, government policies, juridical basis, economic demands, demands for globalization, demands for self-development and opportunities to graduate to continue education or enter society Servaes (2009).

School input is everything that is needed for the education process to take place, especially the teaching and learning process. Inputs are classified into two, namely processed and processed. The input that is processed is the student, and the input from the processor includes the vision, mission, goals, objectives; curriculum; education staff; funds, infrastructure and facilities, school regulations, school organization, school administration, school culture, and the role of the community in supporting schools. The process is the occurrence of changing something into something else. The process includes management, leadership, and especially the teaching and learning process. In education, the process is the occurrence of changes in students' behaviour before undergoing education and afterwards. The quality of the teaching and learning process is very dependent on the quality of the interaction between educators and students Naibaho (2021c). Educator behaviour in the classroom, for example, the clarity of teaching, the use of variations in teaching methods, variations in the use of learning resources and media, teaching enthusiasm, use of question types, class management, use of time, discipline, empathy for students, interpersonal relationships, expectations, innovativeness of teaching, and effective use of teaching and learning principles Wubbels (2011). Likewise, the quality of interaction of students in the classroom is very dependent on the quality of their behaviour in the classroom. Students' behaviour in class, for example, the seriousness of learning, enthusiasm for learning, attention to lessons, curiosity, effort, questions, and readiness to learn (mentally and physically).

Educational output is the result of learning (learning achievement), reflecting how effectively the teaching and learning process is held. Learning achievement is determined by the level of effectiveness and efficiency of the teaching and learning process. Learning achievement is indicated by an increase in basic abilities and functional abilities. The outcome is the long-term impact of the output/learning outcome, both for the individual graduates and the community. It means that if the learning outcomes are good, the impact will also be good. In reality, this is not always the case because many factors outside of learning outcomes influence the outcome. The outcome has two dimensions, namely: (1) opportunities to continue education and employment opportunities, and (2) graduate self-development Nadeak and Naibaho (2020b). A good school can provide many access/opportunities for graduates to continue their following education and the opportunity to choose a job. The school framework as a system can be seen in Table 1 below. If the school wants to do a school analysis, a SWOT (strength, weakness, opportunity, and threat) analysis starts with the outcome and ending in context. If the school wants to solve problems or prepare schools, it starts from the context and ends. This way of thinking is a sequential way of thinking using a systems framework Zhao (2010). 


\begin{tabular}{ll}
\hline Table 1 School Framework as a System \\
\hline Component \\
Context \\
1.Demands for self-development and the opportunity to graduate \\
2. Government and community support \\
3. Government policy \\
4. Legal foundation \\
5. The progress of science and technology \\
6. Community values and expectations \\
7. Economic demands \\
8. Globalization demands \\
1. Vision, mission, goals, objectives \\
2. Curriculum \\
3. Energy \\
4. Learners \\
5. Infrastructure and facilities \\
6. Financing \\
7. School regulations \\
8. Organization \\
9. Administration \\
10. Community participation \\
11. School culture \\
Process
\end{tabular}

Visually, school as a system can be seen in Figure 1 below. If we want to analyze schools, we start with outcomes, outputs, processes, inputs, and end contexts. Conversely, if we want to solve problems or prepare, the direction is reversed, namely starting from the context, input, process, output, and ending with the outcome. It is a coherent system of thinking Hofman et al. (2013).

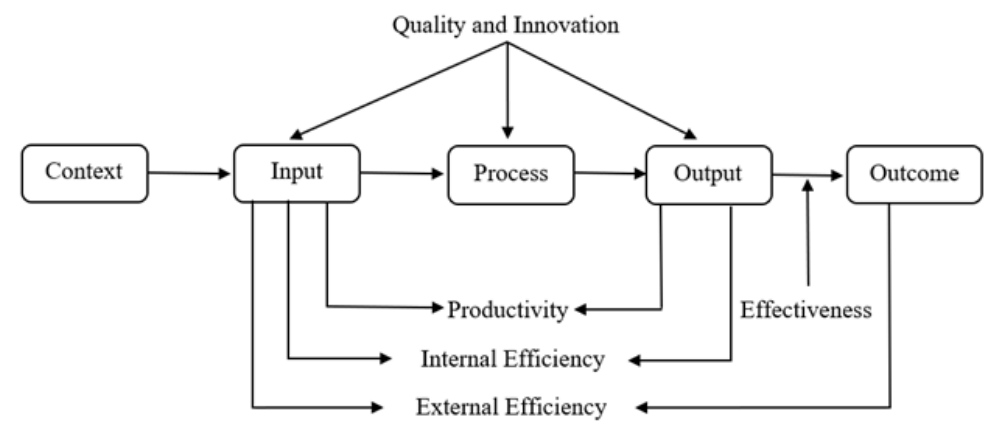

Figure 1 School as a System 
School performance can be measured from the following dimensions, namely quality, productivity, effectiveness, and efficiency, both internal and external. Quality is a comprehensive description and characteristics of a good or service that shows its ability to satisfy specified or implied needs. In the context of education, the quality referred to includes inputs, processes and outputs. Especially for the quality of school output can be categorized into academic and non-academic (for example, sports and arts). The quality of school output is influenced by the level of input readiness and the school process. Productivity is the ratio between school output and school input. Both school output and input are in the form of quantity. Quantity of school inputs, for example, the number of educators/teachers, school capital, materials and energy. The quantity of school output is, for example, the number of students who graduate school each year. An example of productivity, for example, if the school graduated more students than last year with the same input, it can be said that this year the school is more productive than in the previous year.

Effectiveness is a measure that states the extent to which objectives (quality, quantity, and time) have been achieved. Meanwhile, efficiency can be classified into two, namely internal efficiency and external efficiency. Internal efficiency refers to the relationship between school output (achievement of learning achievement) and input (resources) used to process/produce school output. Internal school efficiency is usually measured by cost-effectiveness. Every cost-effectiveness assessment always requires two things: an economic assessment to measure the cost of input (input) and an assessment of learning outcomes (learning achievement, length of study, dropout rate) Hummel-Rossi and Ashdown (2002). Meanwhile, external efficiency is the relationship between the costs used to produce graduates and the cumulative benefits (individual, social, economic, and non-economic) obtained after a long time outside of school. Cost-benefit analysis is the primary tool for measuring external efficiency.

School-Based Management (SBM) is a practical approach that aims to design school management by giving power to school principals and increasing community participation in efforts to improve school performance, including school principals, educators, parents of students, and the community. SBM changed the decisionmaking system by transferring decision-making authority and management to each interested group on each basis (Local Stake Holders). With the SBM concept, it is expected that every school can make continuous quality improvements and have the independence to be more accountable Grinshtain and Gibton (2018).

The PDCA (Plan-Do-Check-Act) circle or PDSA (Plan-Do-Study-Act) is also called the Deming circle because Deming created it. The PDCA circle can also be called the RUAL (Plan-Trial-Observe-Carry out) circle Chen et al. (2016). The circle describes the processes that always occur in every activity or quality performance. The circle can be seen in the following figure:

In every activity or quality improvement effort (quality performance), there are four steps taken or four processes, and the whole is a circle, namely: 


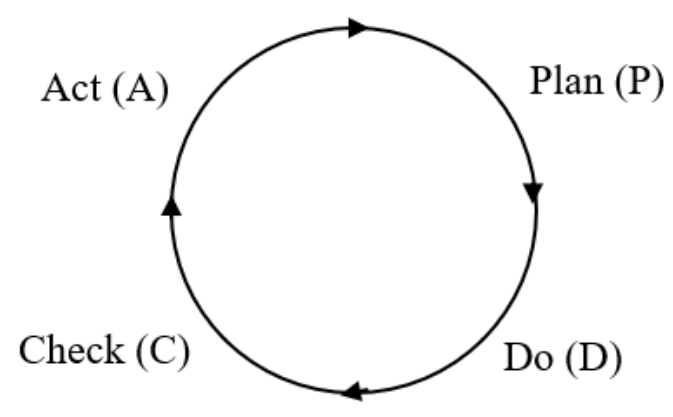

Figure 2 PDCA Circle

1. Plan (P) - The first step, determine the problem that will overcome or the weakness that will improve and draw up a plan (solution) to overcome that problem, which means improving quality.

2. Do (D) - The second step, carry out the plan at the pilot level (U) and improve all processes.

3. Check (C) - The third step, assessing carried out activities and finding weaknesses that need to be fixed, in addition to the things that have been done correctly. Based on these weaknesses, an improvement plan is prepared to be implemented further.

4. Act (A) - The measure, carrying out an increase in incremental enhancement, the weaknesses in number (3). The results are observed, and there are three possibilities: a) The results are of good quality so that the court method can be used in the dating period; b) The results are not quality. It means that the method is not suitable and must be replaced or corrected again in the dating period, and c) The way of listening may be used in different circumstances (other).

Thus, the actual process does not end at step four but returns to step one and so on. Such a circular process occurs in continuous quality improvement.

There are three basic steps to achieve progress; according to Juran, three main steps need to be taken to achieve world-class quality: a) Try to make a structured and sustainable quality improvement with complete dedication and a sense of urgency 1) Quality improvement must be carried out in a planned manner. Therefore, there must be a solid planning system, which focuses on meeting customer needs; 2) Quality improvement must be continuous because customer needs are constantly changing; 3) There must be commitment, persistence and loyalty to all employees, especially leaders Juran and Feo (2010). All must be aware that quality improvement is significant; b) Institute an extensive and robust training program, and c) Adhere to solid determination and good leadership at higher management. Managers and leaders must always be role models. Therefore, even in terms of commitment, they must be role models. 
In quality planning, Juran developed a management system called Strategic Quality Management, which consists of three levels. Each level makes a unique contribution to quality improvement. That way, the division of management functions is clear for unified purposes, not individually. It is one of the main principles of SQM. The three levels are a) Top management is responsible for establishing strategic quality policies. The strategic quality policy includes vision, mission, principles and strategic steps; b) Middle and lower management are responsible for establishing a technical quality policy based on a strategic quality policy. The technical quality policy includes basic technical steps for quality improvement and c) Employees are responsible for quality control in the implementation process Juran (2003). Every employee must understand and consistently obey all the technical steps (procedures) that have been determined in quality improvement.

Based on an analysis using the Pareto diagram, Juran found that most of the problems (weaknesses) in quality improvement efforts reside in the management system, especially in the processes that occur, not in the person. Generally, people's mistakes are due to weaknesses in the system and process. The Thumb Rule 85/15 was found (Role of thumb 85/15), which means that approximately $85 \%$ of the weaknesses are in systems and processes, and only about $15 \%$ in other factors. Therefore, if something goes wrong, do not be the first to be reprimanded or punished, but first, research the systems and processes that occur Bisgaard (2008).

The Juran Trilogy, which is the most important and influential contribution of Juran's thoughts in quality management, which is also an essential aspect of MMT, is the Juran Trilogy, which he sets out in his book Juran On Quality by Design. There are three main management functions in traditional general management, namely planning, implementing, and evaluating. For Juran, the three functions are (1) Quality Planning; (2) Quality Control; (3) Quality Improvement. These three functions are called the Juran Trilogy. There is a specific and systematic sequence of steps in each function, as shown in the table.

Table 2 Juran Trilogy Juran (1986)

\begin{tabular}{|c|c|c|c|c|c|}
\hline \multicolumn{6}{|c|}{ The Juran Trilogy: The Three Functions of Quality Management } \\
\hline No & Quality Planning & No & Quality Control & No & $\begin{array}{c}\text { Quality } \\
\text { improvement }\end{array}$ \\
\hline 1. & $\begin{array}{l}\text { Identify and define } \\
\text { customers. }\end{array}$ & 1. & $\begin{array}{l}\text { Carry out the defined } \\
\text { quality plan following } \\
\text { the specified technical } \\
\text { steps and procedures. }\end{array}$ & 1. & $\begin{array}{c}\text { Analyze the results } \\
\text { of evaluations that } \\
\text { have been carried } \\
\text { out on quality } \\
\text { control } \\
\text { implemented and } \\
\text { determine } \\
\text { weaknesses. }\end{array}$ \\
\hline
\end{tabular}




\begin{tabular}{|c|c|c|c|c|c|}
\hline \multicolumn{6}{|c|}{ Table 2 continued } \\
\hline 2. & $\begin{array}{l}\text { Identify and determine } \\
\text { customer needs. }\end{array}$ & 2. & $\begin{array}{c}\text { Evaluate all } \\
\text { processes/steps during } \\
\text { the process/steps and } \\
\text { record any } \\
\text { errors/weaknesses (if } \\
\text { any). }\end{array}$ & 2. & $\begin{array}{l}\text { Retrying customer } \\
\text { needs. }\end{array}$ \\
\hline 3. & $\begin{array}{c}\text { Planning products } \\
\text { whose properties are } \\
\text { following customer } \\
\text { needs. }\end{array}$ & 3. & $\begin{array}{l}\text { Make improvements to } \\
\text { errors/weaknesses } \\
\text { based on the evaluation } \\
\text { results, as long as the } \\
\text { process is still ongoing. }\end{array}$ & 3. & $\begin{array}{l}\text { Develop a quality } \\
\text { improvement plan } \\
\text { based on data on } \\
\text { weaknesses and } \\
\text { customer needs. }\end{array}$ \\
\hline 4. & $\begin{array}{l}\text { Arrange and determine } \\
\text { the systems and } \\
\text { processes that can } \\
\text { produce the planned } \\
\text { product. }\end{array}$ & 4. & $\begin{array}{l}\text { Conducting a final } \\
\text { evaluation of the } \\
\text { process and product } \\
\text { and taking inventory of } \\
\text { strengths, weaknesses, } \\
\text { and new things for } \\
\text { further quality } \\
\text { improvement. }\end{array}$ & 4. & $\begin{array}{l}\text { Prepare all the } \\
\text { facilities and } \\
\text { infrastructure as } \\
\text { well as the } \\
\text { necessary human } \\
\text { resources. }\end{array}$ \\
\hline \multirow[t]{2}{*}{5.} & $\begin{array}{l}\text { Describe all processes } \\
\text { in the defined system } \\
\text { into activities and } \\
\text { operational (technical) } \\
\text { steps }\end{array}$ & & & 5. & $\begin{array}{c}\text { Forming a } \\
\text { cooperation team } \\
\text { and empowering it } \\
\text { to be able to carry } \\
\text { out quality } \\
\text { improvements. }\end{array}$ \\
\hline & & & & 6. & $\begin{array}{l}\text { Implement quality } \\
\text { improvement plans } \\
\text { with systems and } \\
\text { processes such as } \\
\text { quality control } \\
\text { (back like a circle). }\end{array}$ \\
\hline
\end{tabular}

Furthermore, Juran distinguishes the following definitions of quality, and there are two types of quality: a) Strategic Quality or Great Quality or Macro Quality, namely strategic quality, especially in products that contain strategic policy characteristics; and b) Technical Quality or Small Quality or Micro Quality, namely technical quality, especially on products of a technical nature. Meanwhile, there are two levels of quality management, namely: a) Strategic Quality Management, which is the top quality level that outlines strategic quality policies; and b) Technical Quality Management, which is the level of operational (technical) quality management, which determines technical quality.

The next character is Crosby (Quality Vaccine) - Crosby analogizes quality culture with vaccination. In order for people to be resistant to disease, vaccination is necessary. In the organization (body), the primary bacterial disease is the product's nonconformity with the needs due to specific weaknesses. The product becomes of poor quality, and the organization loses money (sick). To prevent this, it is necessary to hold quality vaccinations, namely instilling the principle (quality) from the beginning and continuously Crosby (1985). 
There are five quality vaccines that Crosby found. The five ingredients are principles in the system that every employee and leader must cultivate. The five ingredients: (1) Integrity, all employees, especially leaders, must have integrity, in the sense of mastering their respective duties, having high commitment and morality. (2) The system must have a solid system, including quality planning, quality plan implementation processes, evaluation for quality improvement, human resource empowerment, and maintenance. Everything moves in an integrated manner to achieve common goals. (3) Communication, the organization must have the best possible information and communication network to know well (well-informed) about all developments in the organization. Openness must develop adequately. (4) Implementation, so that the implementation of all activities runs smoothly, all procedures and technical steps must be appropriately prepared, employee training is carried out regularly, and relationships with suppliers and customers are well developed. (5) Policy, all quality policies are formulated and socialized BANDSUCH et al. (2008). Reports for each quality management function are prepared and communicated in an orderly, objective and transparent manner. Promotion and external relations are continuously improved, and the needs of customers are identified carefully and objectively. For quality culture, in the sense of instilling and growing these five quality vaccine ingredients to all employees and leaders, Crosby proposes three main strategic steps that must be taken: commitment, education/training, and implementation.

Commitment - All employees, especially leaders, must have a strong commitment (determination) to cultivate quality in the entire life of the organization. To form and instil commitment, there are four absolutes (Four Absolutes) that must be understood, lived, and implemented through consistent habituation, namely:

1. Absolute First - Quality is defined as conformity with customer requirements.

2. Absolute Second - The quality system is understood as error prevention

3. Absolute Third - Quality standards of performance are without defects ('Zero Defects')

4. Absolute Fourth - The measure of quality is the cost of nonconformity.

Education / Training - Quality human resources must be available before program implementation (plan). For that, we need an in-service education/training system as part of management. Crosby divides education/training into three levels: a) Executive education/training for top managers; b) Management education/training for middle and lower managers; and c) Employee education/training for all technical (field) employees. The program goals (ability goals) included Crosby called 'The six C's' (Six Cs). For every education/training participant, the six characteristics of the quality of the ability must be present at the end of the program, namely: comprehension, commitment, competence, communication, correction, continuance.

Implementation - After everything has been cultivated and internalized, primarily through education/training, then the quality improvement program and at the same time quality culture will be implemented according to Crosby's fourteen steps. 
The operational steps in the quality improvement effort are as follows: a) Rounding off management commitment; b) Forming a quality improvement team; c) Identifying the main problem; d) Estimating the cost of quality; e) Increase the awareness and commitment of every employee to quality; f) Develop a system of corrective actions; g) Devising a perfect plan; h) Providing education/training for supervisors; i) Organizing days without defects; j) Determining goals; k) Overcoming the causes of error; l) Give recognition; m) Establish and activate the quality board; n) Do it again Adhwarjee et al. (2013).

Crosby's sequence is arranged in such a way; however, it is not a rigid one. Following the situation at hand, necessary changes can be made in the quality improvement process.

Shigeo Shingo was heavily influenced by Juran and Crosby's views, so that his attention shifted from product quality control, which is usually done by inspecting the product alone, to total quality control, which focuses on systems and processes. Juran's 85/15 thumb rule and Crosby's Flawless concept provided the primary basis for developing his practical views. 'Poka-Yoke' is a Japanese term used for the concept of Flawless. He concluded that every process could be observed carefully and continuously. If there is an error, the process must be paused, and the source of the error and its root must be found, then repaired immediately.

Ishikawa uses statistical principles in developing quality control techniques. One of his notable contributions is the Fishbone Diagram or Ishikawa diagram, which is very effective as a problem analysis or causal analysis tool. With this diagram, the source of the cause and the problem can be found so that the solution can be worked out more precisely. By dealing with the root cause, no similar problem will arise. Ishikawa formed the Quality Society (Quality Circle) in Japan, whose members consist of quality experts. This function of the Quality Society encourages the development of quality culture movements, provides suggestions on quality improvement, and monitors the implementation of quality improvement efforts. In line with the quality society, he also proposed a cooperation team for quality improvement in companies, which has the function of carrying out quality improvement activities Mizuno (2020).

Taguchi's contribution to quality improvement techniques is contained in three main concepts: a) Quadratic Loss Function; b) Design Parameters; c) Planned Experiments based on statistics. The concept of the quadratic loss function is an application of the Crosby concepts of 'Quality is not expensive, 'without defects', and 'cost of quality. In the Taguchi concept, quality is understood in terms of unqualified products. The cost of inferior quality products is ultimately higher, so control of the process from the outset is significant. With the concept of Parameter Design, Taguchi argues that diversity causes errors. That way, quality products can be reduced if the measurements (parameters) in all production processes are determined in a thoughtful and detailed manner. Then, in practice, all are carefully monitored from the very beginning [44]. 
School is a place for prospective scientists and skilled, educated personnel to be seeded, ready to build their society and nation. Schools as agents of renewal have a significant role in this highly competitive global era. Aware of its position and role, the school is tasked with providing a quality learning process, with the hope of producing graduates who are intelligent, skilled, have good character, and can enter the national and global job market. To build quality schools, various requirements are needed, regulations are needed following the development of schooling in Indonesia. In addition, management autonomy is needed that provides flexibility for school principals to organize themselves according to the conditions of the school they lead. The emergence of awareness that various problems always arise during the implementation of activities, so the ability to detect early problems that arise and those that will arise is needed to be adequately anticipated. Especially in very uncertain situations, then 'prevention before falling ill is more important than treating it.

\section{CONCLUSION}

From the explanation above, it can be concluded that school principals and educators must be equipped with competency-based education that is life skills-oriented, both general skills such as personal skills and social skills and special skills such as academic skills and vocational skills. In this case, each subject is a "tool" to develop life skills that students can use to face real life. In learning activities, efforts should be made to use contextual learning and teaching by actively interpreting and understanding new teaching materials. In solving problems, encouraging students so that the concepts learned can be applied in everyday life, and teaching materials can be processed into parts from his knowledge, always remembering that in education, besides output, the process is also essential! Various factors determine the success of a school. Excellent and correct management, commitment from all elements involved in school management. Parents of students and community members who are members of the school committee and the school environment. For management to run smoothly, to be a matter of pride, democratic educational leadership must apply the principles of transparency and professionalism. If this principle is applied correctly and can optimize community support and participation, it will be an asset to create a strong/superior school. Finally, a solid commitment to jointly realize the vision and mission of the school, principals and educators/teachers must work optimally following their duties and obligations, namely leading, managing, educating and teaching their students and vice versa students must also show fierce commitment to learning diligently, tenaciously, smartly and ready to become human learners. and able to learn lifelong (lifelong learning). Likewise, parents of students are obliged to encourage and always remind their children to learn appropriately and well (parents are the first and foremost educators for their children). Meanwhile, other community members must also pay attention to the school, and function as social control, so that the school can continue to run and develop according to its track. 


\section{REFERENCES}

Adhwarjee, D. K., Majumder, M., \& Banerjee, N. I. L. O. T. P. A. L. (2013). Exploring Crosby's Fourteen Steps To Quality Improvement Applied To Industry. International Journal of Innovative Technology And Research(1), 544-546.

BANDSUCH, M., PATE, L., \& THIES, J. (2008). Rebuilding Stakeholder Trust in Business: An Examination of Principle-Centered Leadership and Organizational Transparency in Corporate Governance. Business and Society Review, 113(1), 99-127. Retrieved from https://dx.doi.org/10.1111/j.1467-8594.2008.00315.x 10.1111/j.1467-8594 .2008.00315.x

Bisgaard, S. (2008). Quality Management and Juran's Legacy. Quality Engineering, 20(4), 390401. Retrieved from https://dx.doi.org/10.1080/08982110802317398 10.1080/ 08982110802317398

Bush, T. (2006). Theories Of Educational Management. International Journal Of Educational Leadership Preparation, 1(2), 2-2.

Chen, P., Yuan, T., Sun, Q., Jiang, L., Jiang, H., Zhu, Z., Xu, .., \& A. (2016). Role Of Quality Control Circle In Sustained Improvement Of Hand Hygiene Compliance: An Observational Study In A Stomatology Hospital In Shandong. China. Antimicrobial Resistance \& Infection Control, 5(1), 1-6.

Cheng, Y. C., \& Chan, M. T. (2000). Implementation Of School-Based Management: A MultiPerspective Analysis Of The Case Of Hong Kong. International Review Of Education, 46(3), 205-232.

Crosby, P. B. (1985). Quality Without Tears. New American Library.

Esteves, A. M., \& Vanclay, F. (2009). Social Development Needs Analysis as a tool for SIA to guide corporate-community investment: Applications in the minerals industry. Environmental Impact Assessment Review, 29(2), 137-145. Retrieved from https://dx.doi .org/10.1016/j.eiar.2008.08.004 10.1016/j.eiar.2008.08.004

Grinshtain, Y., \& Gibton, D. (2018). Responsibility, authority, and accountability in schoolbased and non-school-based management. Journal of Educational Administration, 56(1), 2-17. Retrieved from https://dx.doi.org/10.1108/jea-01-2017-0005 10.1108/ jea-01-2017-0005

Hadijaya, Y. a. (2015). School Based Management at Matauli 1 State Senior High School Pandan. Researchers World - Journal of Arts Science \& Commerce, 6(4), 55-66. Retrieved from https://dx.doi.org/10.18843/rwjasc/v6i4/08 10.18843/rwjasc/v6i4/08

Hofman, R. H., Boom, J. D., Meeuwisse, M., \& Hofman, W. A. (2013). Educational Innovation, Quality, And Effects: An Exploration Of Innovations And Their Effects In Secondary Education. Educational Policy, 27(6), 843-866.

Hummel-Rossi, B., \& Ashdown, J. (2002). The State of Cost-Benefit and Cost-Effectiveness Analyses in Education. Review of Educational Research, 72(1), 1-30. Retrieved from https://dx.doi.org/10.3102/00346543072001001 10.3102/00346543072001001

Juran, J. M. (1986). The Quality Trilogy. The Quality Trilogy. Quality Progress, 19, 19-24.

Juran, J. M. (2003). Simon And Schuster. Juran On Leadership For Quality.

Juran, J. M., \& Feo, J. A. D. (2010). Juran's Quality Handbook: The Complete Guide To Performance Excellence. Mcgraw-Hill Education. Juran's Quality Handbook: The Complete Guide To Performance Excellence.

Katuuk, D. A. (2014). Evaluation On School Based Management Implementation In Elementary School At Tomohon City. North Sulawesi. Evaluation(7), 5-5.

Kolibu, D. R., Peter, R., Naibaho, L., Paparang, S. R., \& Hanock, E. E. (2021). Strengthening The 
Values Of Christian Education In Facing The New Normal Era. Psychology And Education Journal, 58(2), 10937-10944.

Komoldit, K., Tawisook, M., \& Pilanthananond, N. (2018). Graduate School Management Characteristics to Ensure Production of Quality Graduates for Sustainable Competitiveness. Mediterranean Journal of Social Sciences, 9(4), 121-129. Retrieved from https:// dx.doi.org/10.2478/mjss-2018-0121 10.2478/mjss-2018-0121

Kristiana, M. D. (2019). Legal Reform On Indonesian Education Policy. Politics Of Law On School Days Policy: Legal Reform On Indonesian Education Policy. Journal of Law And Legal Reform, 1(1), 5-24.

Malhoit, G. C. (2005). Providing Rural Students With A High Quality Education: The Rural Perspective On The Concept Of Educational Adequacy. Rural School And Community Trust.

Mizuno, S. (2020). Management For Quality Improvement. Management For Quality Improvement: The 7 New QC Tools.

Nadeak, B., \& Naibaho, L. (2019). Managing Lecturers' Competence Development At Universitas Kristen Indonesia. Managing Lecturers' Competence Development At Universitas Kristen Indonesia.

Nadeak, B., \& Naibaho, L. (2020a). MOTIVATION AND HRM FACTORS RELATION TO THE EMPLOYEE LOYALTY. Polish Journal of Management Studies, 22(2), 261-276. Retrieved from https://dx.doi.org/10.17512/pjms.2020.22.2.18 10.17512/pjms.2020.22.2.18

Nadeak, B., \& Naibaho, L. (2020b). Video-Based Learning On Improving Students'learning Output. Palarch's. Journal Of Archaeology Of Egypt/Egyptology, 17(2), 44-54.

Nadeak, B., Naibaho, L., \& Silalahi, M. (2020). COVID-19 And Students' Anxiety Management. International Journal of Innovation, Creativity And Change, 13(7), 1574-1587.

Nadeak, B., Naibaho, L., Sunarto, S., Tyas, E. H., \& Sormin, E. (2021). Learning Management In Suburban Schools During The Midst Of COVID-19. Psychology And Education Journal, 58(2), 1131-1139.

Naibaho, L. (2014a). The Role Of Education And Culture In The Development Of Character And Civilization Of The Plural Indonesian Nation. Jurnal The Ary Suta Center Series On Strategic Management, 27(0), 69-69.

Naibaho, L. (2014b). The Role Of Education And Culture In The Development Of Character And Civilization Of The Plural Indonesian Nation. Jurnal The Ary Suta Center Series On Strategic Management, 27(0), 69-69.

Naibaho, L. (2021a). Online Learning Evaluation during Covid-19 using CSE-UCLA Evaluation Model at English Education Department Universitas Kristen Indonesia. Budapest International Research and Critics Institute (BIRCI-Journal): Humanities and Social Sciences, 4(2), 1987-1997. Retrieved from https://dx.doi.org/10.33258/birci.v4i2.1887 10.33258/birci.v4i2.1887

Naibaho, L. (2021b). Pre-Service Teachers' Soft Skills And Achievement. Turkish Journal of Computer And Mathematics Education (TURCOMAT), 12(10), 491-496.

Naibaho, L. (2021c). Psycholinguistics In Language Learning. Psycholinguistics In Language Learning.

Nugroho, Y. (2010). NGOs, THE INTERNET AND SUSTAINABLE RURAL DEVELOPMENT. Information, Communication \& Society, 13, 88-120. Retrieved from https://dx.doi.org/ 10.1080/13691180902992939 10.1080/13691180902992939

Reeves, D. B. (2009). How To Conquer Myths, Build Commitment, And Get Results. Ascd. Leading Change In Your School: How To Conquer Myths, Build Commitment, And Get Results.

Schwab, K., \& Sala-I-Martín, X. (2013). The Global Competitiveness Report. Full Data Edition. 
World Economic Forum.

Servaes, J. (2009). Communication policies, good governance and development journalism. Communicatio, 35(1), 50-80. Retrieved from https://dx.doi.org/10.1080/ 02500160902906653 10.1080/02500160902906653

Traitler, H. (2015). The Food Industry Innovation School. The Food Industry Innovation School: How To Drive Innovation Through Complex Organizations.

Tyas, E. H., \& Naibaho, L. (2021a). HOTS LEARNING MODEL IMPROVES THE QUALITY OF EDUCATION. International Journal of Research -GRANTHAALAYAH, 9(1), 176182. Retrieved from https://dx.doi.org/10.29121/granthaalayah.v9.i1.2021.3100 10 .29121/granthaalayah.v9.i1.2021.3100

Tyas, E. H., \& Naibaho, L. (2021b). MANAGING TRI PUSAT PENDIDIKAN IN THE COVID -19 PANDEMIC. International Journal of Research -GRANTHAALAYAH, 9(4), 492500. Retrieved from https://dx.doi.org/10.29121/granthaalayah.v9.i4.2021.3893 10 .29121/granthaalayah.v9.i4.2021.3893

Tyas, E. H., Sunarto, S., \& Naibaho, L. (2020). Building Superior Human Resources Through Character Education. TEST Engineering \& Management, 83, 11864-11873.

Venter, H. (2006). The Performance Management System For Educational Staff At Motheo College. The Performance Management System For Educational Staff At Motheo College: An Evaluative Case Study (Doctoral Dissertation.

Wubbels, T. (2011). An international perspective on classroom management: what should prospective teachers learn? Teaching Education, 22(2), 113-131. Retrieved from https://dx.doi.org/10.1080/10476210.2011.567838 10.1080/10476210.2011 .567838

Zhao, J. (2010). School Knowledge Management Framework And Strategies: The New Perspective On Teacher Professional Development. Computers In Human Behavior, 26(2), 168-175. 